\title{
Humanizing Finance by Hedging Property Values
}

\author{
Jaume Roig Hernando \\ Polytechnic University of Catalonia, Barcelona 08014, Spain; jaume.roig.hernando@upc.edu; \\ Tel.: +34-605-271-173 \\ Academic Editor: Donald Lien \\ Received: 13 March 2016; Accepted: 30 May 2016; Published: 10 June 2016
}

\begin{abstract}
The recent financial crisis triggered the greatest recession since the 1930s and had a devastating impact on households' wealth and on their capacity to reduce their indebtedness. In the aftermath, it became clear that there is significant room for improvement in property risk management. While there has been innovation in the management of corporate finance risk, real estate has lagged behind. Now is the time to expand the range of tools available for hedging households' risks and, thus, to advance the democratization of finance. Property equity represents the major asset in households' portfolios in developed and undeveloped countries. The present paper analyzes a set of potential innovations in real estate risk management, such as price level-adjusted mortgages, property derivatives, and home equity value insurance. Financial institutions, households, and governments should work together to improve the performance of the financial instruments available and, thus, to help mitigate the worst impacts of economic cycles.
\end{abstract}

Keywords: household portfolio management; property finance; risk management; behavioral finance; financial institutions; government policies

\section{Introduction and Objective}

This paper aims to propose ways of encouraging the democratization of finance, specifically in the area of real estate risk management. Despite the increase in the complexity of both the financial markets and information technology, the owner-occupied finance industry has advanced very little in recent decades.

Real estate is an important, if not the most important, storage of wealth in the economy. On average, households in developed countries have an excessive property allocation with an exposure of between $40 \%$ and $70 \%$. Therefore, the wealth effect of changes in house prices is much larger than in other asset prices [1].

As changes in real estate values impact the well-being of millions of people, strong grounds are needed for improving property risk management and creating hedging instruments. During the financial crisis, outdated mortgage products based on the payment of monthly instalments did not help households to adapt to falling incomes; therefore, a thorough study of property finance innovations is needed, all the more so because the cyclical nature of property markets has direct consequences for the wealth of society [2].

The financial industry, governments, and international institutions should work to establish innovative approaches which can avoid negative future impacts on households' wealth and can obtain positive externalities from the promotion of mortgage lending.

\section{Methodology}

The methodology applied in the study is outlined below.

First, we analyze the current context and framework proposed by academics for managing households' real estate risk. We highlight studies on hedging values [3-8] and on hedging incomes [8-10]. 
Second, we carry out a market study of the hedging instruments currently on the market in order to characterize both the present framework and the main areas for improvement. Various financial entities are examined through interviews and data collection in order to assess the situation of hedging instruments in the market and to relate it to the mainstream academic theories.

Third, we perform an academic analysis of risk management and also provide a broad overview of the state of the art of hedging household property equity.

Fourth, we apply the alpha concept. The alpha coefficient corresponds to the rate of return that exceeds what was expected or predicted by valuation models such as capital asset pricing models. The alpha formula is:

$$
R_{i, t}-R_{f}=\alpha_{i}+\beta_{i}\left(R_{M, t}-R_{f}\right)
$$

where $R_{i}$ corresponds to the (expected) return on the capital asset; $R_{f}$ corresponds to the risk-free rate of interest; $R_{M}$ corresponds to the (expected) return of the market; $\beta_{i}$ corresponds to the sensitivity of the expected excess asset returns to the expected excess market return; and $\alpha_{i}$ corresponds to the performance of a portfolio in relation to a benchmark.

Finally, a Loan-to-Value analysis is provided to identify the evolution and determinants of households' indebtedness; this ratio reflects the weight of the debt over the value of an asset.

$$
\text { LOAN-TO-VALUE }(\text { LTV })=\frac{\text { AGGREGATE LOAN VALUE }}{\text { APPRAISAL VALUE }}
$$

where the aggregate loan value corresponds to the aggregate principal balance(s) of all mortgages on a property and the appraisal value corresponds to the opinion of the value of real property, that is, the estimated amount for which an asset or liability should exchange on the valuation date between a willing buyer and a willing seller in an arm's length transaction, after proper marketing and in an agreement in which both parties have acted knowledgeably, prudently and without compulsion.

\section{The Need for Innovation in Property Risk Management for Households}

\subsection{Why a New Famework is Needed to Manage Household Property Risk}

The development of the finance and banking industries has contributed to economic growth [11]. According to Patrick [12], there is a positive correlation between economic development, the variety of financial institutions and the number of financial assets; so, the launch of innovative products such as loan-based-crowd funding, Real Estate Investment Trusts (REITs), or hedging instruments is the way to democratize finance [13].

In this context, there is a clear need for innovative financial instruments that can help to soften future impacts on households' wealth. Therefore, risk-sharing tools should be created to improve risk management and to help this most vulnerable segment of society. As in the case of savings for retirement or public health care, institutions should lead the democratization of finance by providing incentives to innovate and by helping to launch new real estate finance products that can improve the management of the risk involved.

Since homes are a primary need, the development of real estate finance on the basis of democratization and innovation is a source of economic growth. Governments should encourage innovation by providing incentives for research: for example, through fiscal incentives for financial entities brave enough to launch innovative products that provide financial advantages for households. However, some may still think that the costs of adjusting markets are higher than the costs that a free market can generate; recent events have changed the mindset of political and economic leaders.

Some eight years have passed since the financial and real estate crisis and several developed countries have received huge bailouts, but there has not been any significant development in property hedging products. A great deal of work remains to be done. 


\subsection{Lack of Real Estate Financial Innovation Post-Crisis}

The main risks households face when financing a property are liquidity, capital value variations, and cash flow generation in order to pay down the loan. Despite the significant evolution of the financial markets during the second half of the twentieth century, mortgage contracts have hardly changed since the launch of the long-term fixed-rate self-amortizing mortgage introduced in the US in the 1930s [14]. The main innovations have been the extension of the credit period and the introduction of fixed or variable interest payments. Mortgage providers also offer hedging products such as payment by instalments or the freezing of mortgage payments in case of job loss for a certain period of time, or a mortgage insurance in case of death of the credit holder.

A certain amount of regulation was introduced after the financial and real estate crisis, notably the Dodd-Frank Act in 2010, but financial institutions are again lending at loan-to-value ratios close to $100 \%$ [15]. The softening of credit standards is a questionable policy considering the risks undertaken both by the mortgagor and the financial institution itself-all the more so if one thinks that financial entities are not offering innovative tools for risk management [16]. Therefore, households will be highly vulnerable to future crises. Moreover, as a consequence of the lemon market, banking entities charge households and small and medium enterprises more for capital, thus damaging the financial structure of these more vulnerable segments [17].

\subsection{Excessive Risk-Taking by Households and the Leverage Cycle}

Households' debt during the boom increased significantly and presented enormous differences between regions. These differences are difficult to explain using a purely rational approach. A behavioral approach, however, can identify several triggers that can elicit particular responses: an aggressive financial marketing campaign, limited financial knowledge, herd behavior, the fear of regret, excessive optimism, momentum investing, the gambler's fallacy, or cognitive dissonance.

For Glick and Lansing [18] there is a consistent leverage cycle, and during bubble periods there is a high risk that the debt will exceed the collateral. This may have dramatic negative effects, such as foreclosures or undiversified asset portfolios, as Geanakoplos [19] suggests. Therefore, it is important that public institutions manage the leverage cycle.

From the perspective of households, it is clear that real estate finance must introduce greater innovation in order to improve risk management, diversification, and hedging.

\section{A New Framework for Owner-Occupied Property Finance: Hedging Housing Value Risk}

Despite the importance of hedging property values, the market had few hedging instruments available at the start of the recent crisis, as the former Federal Reserve Chairman, Ben Bernanke, highlighted [20]. Capital value risk, which is correlated with macroeconomic conditions, credit market conditions, regional economy conditions and consumer behavior [21], affects not just households, but also lending institutions, investors in structured products backed by residential mortgage loans, and in fact the economy as a whole [22].

Below we highlight a series of proposals for hedging property value through four main themes: mortgage innovation, insurance, property derivatives, and hedging alternatives.

\subsection{Innovation in Mortgage Agreements}

\subsubsection{Home Equity Fractional Interest}

Home equity fractional interest (HEFI) allows homeowners to hedge property values in a scenario of residential price deterioration. Through this agreement, a foreclosure can be avoided: the lender agrees to reduce the mortgage principal in exchange for equity but allows the household to retain the use of the dwelling. Then, if property values rise, the financial entity obtains a part of the home's price appreciation (which will be materialized when the home is sold) without making any economic contribution. 
By contrast, homeowners also participate in potential future appreciations [23]. This system bears similarities to both, shared appreciation mortgages agreements and housing partnerships but with the difference that, to some extent, HEFI hedges the property value. Shared appreciation mortgages can partly hedge households' incomes, because they allow the financing of a property with a modest or zero cost of capital in exchange for the share of the collateral value appreciation; furthermore, housing partnerships consist in institutional investors purchasing a portion of the equity in owner-occupied homes from homeowners who want to sell; doing that, large investors diversify the risks of their portfolios, and obtain a hedge against inflation.

Finally, HEFI can be used by homeowners with positive equity in their home (that is, Loan-to-Value rates below 100\%) who wish to convert part of their net worth into cash, or also by prospective homeowners who can obtain a mortgage on better terms (e.g., at a reduced cost of capital). With this type of mortgage, they renounce a part of the potential appreciation of the home's value.

\subsubsection{Price Level-Adjusted Mortgages}

Price level-adjusted mortgages (PLAM) are mortgages with instalments adjusted to an index, usually to inflation [4]. Instalments are constant over time in real terms but not nominally, unlike fixed payment mortgages. With this system, interest rates remain fixed but the outstanding principal balance fluctuates [16].

PLAM allow monthly payments to be adapted to the trend of wealth increase in nominal terms; that is, the payments varies according to the rate of inflation, but the value of the mortgage remains constant and the interest rate does not change. This allows a better alignment of households' incomes and instalments; previously, the mismatch between the two caused millions of people to struggle when the economic cycle entered a downward turn.

Moreover, financial institutions are able to offer mortgages at a competitive cost of capital as they do not need to include the forecast inflation. Nonetheless, instalments oscillate periodically, which makes it difficult for households to forecast their outflows. Moreover, in the case of deflation, the hedge may lose value.

\subsection{Home Equity Value Insurance}

Two main types of home equity value insurance are potentially developable: fixed-fee and pass-through insurance.

In fixed-fee insurance, the policyholder transfers to the insurer the risk of the hedge by paying an insurance premium. Price changes are defined by a real estate price index in which insurance companies take short or long positions in real estate futures markets in order to hedge their agreement with the household [7].

For its part, pass-through insurance is based on futures and options on real estate price indices which are passed through to the homeowner as an insurance product. The insurance company then sells off the risk that incurs in writing home equity insurance policies and manages only the technical aspects of the coverage. For example, with pass-through futures, homeowners see their accounts debited or credited depending on the change in the real estate futures price on which their policy is based. However, as with shared appreciation mortgages, individuals are reluctant to lose the potential price increases of their homes, especially when they have to pay for the hedge in upturn scenarios. In the same way as the coverage of damage to the home is required by law, some type of regulation or innovation could be introduced to guarantee the property's value.

Fixed-fee insurance is very attractive for the market as it hedges price declines and enables households to take advantage of price increases via a simple booking process. However, pass-through insurance can be offered at a more competitive price, as households assume part of the risks of the hedge. An example of an attempt to create an insurance against falls in home equity was set in motion in Chicago in 1978: it covered $80 \%$ of the loss incurred if the home was sold for less than the appraised value. 
However, this kind of insurance has certain disadvantages. The first is the situation of moral hazard in relation to home owners, who may not keep their homes in good condition if they know that the value is insured, or they may not wish to sell their homes advantageously and just sell to the lowest bidder. Another issue is the choice of the price index to value the asset.

\subsection{Real Estate Derivatives}

Derivatives help to achieve something that the purchasing of single properties is unlikely to obtain: that is, a diversified property portfolio without specific risks that replicates the total property market. Shiller [24] highlighted the near absence of derivatives markets for real estate compared to stocks, even though the value of real estate held by households is well above the stock market value.

Real estate derivatives correspond to securities whose price is related to the underlying assets, in this case, properties. They are usually commercialized in the form of total return swaps, forward contracts, futures, bonds, or note structures. Trading or taking positions in property derivatives is also known as synthetic real estate.

Like securitization, derivatives transactions incur minimum legal fees and transaction costs, and so they provide less expensive access to real estate exposure than investing directly or via other indirect methods. Moreover, these instruments allow smaller-scale investors to mitigate the negative effects of investing in direct real estate, such as specific risk, illiquidity, or high transaction costs.

Indeed, the low correlation between housing prices and equity prices has a positive impact on portfolios that include direct or underlying property assets $[6,25]$. Since real estate markets represent such a high proportion of the world market, there is no way of achieving market beta with a portfolio that does not include real estate.

In addition, one of the most interesting points about derivatives is that they improve the management of property risk, such as property value. They are commonly used to take contrary positions to the price movements of a property index in order to obtain coverage and to reduce exposure to the property market.

In summary, real estate derivatives are a potentially powerful tool for managing households' risks insofar as they reduce capital value risk and volatility risk, improve price discovery and spot markets, facilitate the development of structured products, and improve portfolio diversification and correlation.

\subsubsection{Entry Barriers to Property Derivatives}

Unfortunately, property derivatives have not established themselves in the mainstream financial markets because of the existence of certain entry barriers to their development.

The lack of homogeneity of the underlying assets makes it harder to find an index that aggregates real estate market information and is able to provide an accurate representation of the underlying performance of the real estate assets. This situation is compounded by property market inefficiencies [17]. Another entry barrier to property derivatives is the lack of liquidity, mainly due to the predictability of returns which does not allow the identification of a significant number of counterparties that take a position against the market trend.

Secondly, and in relation to the above, owners are reluctant to commercialize at a price below their reference value, which is normally equivalent to the purchase price [1].

The most widely used model for forecasting derivatives prices, the Black-Scholes Model, is unlikely to be appropriate in the case of property derivatives because the underlying assets do not comply with the assumptions of the model, e.g., a risk-neutral framework. Alternative derivative valuations that assess the characteristics of properties have been suggested (e.g., [26]).

\subsubsection{Hedging against Property Downturns}

Derivatives can be used to enhance the management of cyclical risk in the property market. During real estate downturns, derivatives allow investors to sell their market exposure for 
a predetermined time, while retaining the ownership of their preferred assets. This position effectively hedges market exposure and allows investors to retain any excess stock performance; that is, the alpha of the asset, generated by the management of the physical assets [27].

For instance, if a portfolio is overweight in a specific region, it can either sell assets, losing potential price increases, or contract a derivative instrument that enables it to retain the alpha while reducing tracking error and maintaining the portfolio, but swapping out of the regional index performance.

\subsubsection{The New Framework of Property Derivatives}

Various types of derivatives developed by academics or already marketed are discussed below. We evaluate their suitability for introduction and/or consolidation in the real estate industry.

\section{Single Specific Property Swap}

The simplest real estate derivative involves a single specific property swap in which an owner swaps the returns and risk of a property for the returns and risk of another property owned by a third party. The costs of this agreement are low because no transaction costs are incurred.

On the negative side, this agreement may create potential conflicts of interest because each owner is giving away the returns on the assets they own [27].

\section{Property Sector Swaps}

A more complex hedging strategy involves switching residential indices in order to rebalance a portfolio, or as an investment strategy which may include a premium or discount of one city to another.

Unlike the previous case, there are no conflicts of interest because owners are able to maintain the potential alpha. For example, a homeowner could switch a city or region residential index for another city or region residential index as a hedge in the case of wanting to move.

Total return swaps can be considered as a type of property sector swap.

\section{Hedging Values of the Property Abroad}

The acquisition of properties by households abroad has increased exponentially in recent decades. This trend may increase further if the property risks are manageable.

The limited knowledge of market trends in foreign countries may lead to biased investment decisions, such as the acquisition at a price significantly different from the property fundamental value. This is where derivatives can participate in hedging property values.

Therefore, homeowners can obtain a country hedge by reducing their exposure in a country index and taking long positions in others.

\section{Structured Real Estate Index Notes}

Real estate structured notes are bonds that pay a coupon linked to the performance of a real estate index [27].

Unlike swaps, the acquisition of these assets involves the payment of the asset price at the beginning of the trade, granting the investor the right to receive the coupon; at the end of the contract, the investor receives the nominal value of the asset.

Through this product, households can create the exposure they desire in order to hedge against property values.

\section{Traded Index Futures}

A traded future is a contract traded on a futures exchange to buy or sell a standardized quantity of a commodity with homogeneous quality at a certain date in the future, at a price (the futures price) determined by supply and demand. 
In 2009, Frankfurt-based Eurex launched the first exchange-traded property futures and options, with an AAA- qualification, which made it possible to invest, hedge, or underwrite property contracts and ensure that losing positions could be covered. This example demonstrates that property futures can be used for the diversification of an investment portfolio, for speculation with leverage, or for hedging property values: diversification because, rather than acquiring a few individual stocks, they make it possible to track stock indexes that provide exposure to the whole market or to a market sector; speculation, because thanks to leverage with a small investment, it is able to obtain extensive exposure by controlling a greater amount of capital and, in case of small changes in the index level, it produces a profit or a loss depending on the market's direction.

Paulson and Co, an investment management firm, provides a clear example of this practice; by betting on property market failure through short sells, they obtained huge yields thanks to the failure of the financial and real estate markets. According to Shiller [28], Paulson's behavior is an example of a constructive capitalist response to excesses in the market, since the firm used a synthetic collateralized debt obligation to express the opinion that property assets were overpriced.

Finally, this system enables households to protect against a decline in property values, in particular during times of uncertainty. Households can reduce their exposure by using traded index futures without the need to sell their first residence or other properties that they may own.

Synthetic Options

More advanced than traded index futures, synthetic options correspond to the use of property derivatives together with other financial instruments that can mimic the financial performance of an income-producing asset: a synthetic income property.

Synthetic options combine a cash or futures position with an option in order to reduce some of the risks of a single option exposure. The cash or futures position is the primary position, and the option is the protective position.

Two types of synthetic options exist in the market: (i) the synthetic call, in which an individual is both long in the cash or futures position and acquires a put option; and (ii) the synthetic put, in which an individual is short in the cash or futures position and purchases a call option.

Thanks to this double position, the synthetic call or put limits the potential profit and loss of a regular put or call option. This enables individuals to limit their risk to futures with this double position and to hedge against price movements. In this way, real estate investors can benefit from hedging strategies against rises and falls in home prices.

Real Cases of Property Derivatives and Potential Improvements

Let us look now at some real cases of property derivatives. On 9 May 1991 the London Futures and Options Exchange introduced four property futures contracts to allow the development of hedging instruments, arbitrage, and price discovery in the commercial and residential markets. Contracts were based on housing and mortgage interest rate indices. However, the plan did not prosper, due to an inadequate underlying index [3].

In 2003, Goldman Sachs launched covered warrants and, in 2007, Morgan Stanley issued a swap with a value of more than $£ 1$ million with a defined structure of gains and losses depending on the index evolution. Other examples of homeowner derivatives are found in the Chicago Mercantile Exchange in 2006 and in the Chicago Board Options Exchange in 2012, but neither plan managed to become consolidated.

Derivatives for Commercial properties such as the Investment Property Databank (IPD) or the S and P/GRA Commercial Real Estate Indices are building up significant momentum. One achievable innovation corresponds to adapting commercial property derivatives to residential derivatives, taking into account, for example, the fact that thirteen investment banks are licensed to trade in the real estate IPD index, or that the derivatives market in 2007 in the United Kingdom, Germany, Switzerland, Italy and France amounted to $£ 8.30$ billion. However, it should be considered that the behavior of 
commercial property markets differs from the residential ones, meaning that it is necessary to manage their idiosyncrasies.

\subsection{Hedging Alternatives for Property Prices}

\subsubsection{Financial Leasing}

Financial leasing is a commercial agreement in which a financial institution purchases an asset which is rented to the customer, who pays instalments. The unusual feature is that the customer has an option to acquire ownership at the end of the period of the contract.

Financial leasing is not one of the standard products offered by financial institutions. Its use has been focused on corporate buildings. From a tenant point-of-view, financial leasing offers the right of use in exchange for paying the lease fee and keeping the purchase option, which amounts to a hedging property value. Moreover, households avoid having to make substantial initial financial assignments, thus, reducing their risks.

For its part, the financing institution initially buys the asset which, afterwards, will be rented to the tenant with a purchasing option and, thus, obtains an interesting yield throughout the lease of the asset.

\subsubsection{Lease-Purchase Agreements}

Lease-purchase agreements, like financial leasing, allow households to use the property in exchange for a lease fee but with an option to acquire the property at a certain date.

The main difference between financial leasings and the lease-purchase agreement is that, in the latter, the owner is usually a real estate company or a homeowner willing to sell the property who decides to sign this type of agreement due to a negative financial climate or a low liquidity property and is reluctant to lose the opportunity to obtain cash flows through leasing and potential subsequent sale.

Moreover, the lessees and potential buyers hedge the value of the asset by being able to use the product and by establishing whether it conforms to their needs.

\subsubsection{Can Owning a Home Hedge the Risk of Moving?}

Moving risk is an important factor in the decision-making process regarding the purchase of a home. The rate of residential mobility in Europe varies considerably; it is high in Nordic countries and low in Eastern and Southern Europe. Mobility depends on transaction costs, housing supply, rent controls, tenant protection and access to credit [29]. In scenarios where households face a greater risk in moving, they are likely to rent rather than buy a home.

Despite the lack of derivatives for hedging values in the real estate market, according to Sinai and Souleles [22], buying a home can be an efficient hedge against price volatility when managing mobility risk. This is because households should evaluate the uncertainty of their total lifetime housing costs, and because there is a positive expected covariance of residential prices between their current and new location, given that households do not move to random locations. So, owning a home in one's home city is a price hedge for the risk of moving to a new property market.

\section{Public Incentives for Developing Property Hedging Instruments}

This paper has highlighted the economic aspects of housing. However, housing is a basic need and right; it has a vast social dimension as well. Among the countries most severely affected by the financial crisis, Ireland has 400,000 households experiencing negative equity, and both Spain and Greece have 500,000 households under threat of eviction [30]; in the US, 15 million Americans are suffering a negative net worth in their homes [31], and between $7 \%$ to $11 \%$ of UK owner-occupier mortgagors were in negative equity in spring 2009 [32]. Moreover, negative equity usually affects the most vulnerable social groups, such as the young [33]. 
In spite of the chairman of the Federal Reserve's warning that the private sector should provide home equity insurance to help protect individual homeowners against market declines [20], the present paper and others have shown that the private sector lacks incentives to introduce hedging property value instruments, and according to Shiller [9], to ensure that risk sharing proceeds on a truly massive scale, public advocacy by international economic development organizations, labor unions, and professional organizations is required considering that the benefits of such risk sharing are not so obvious to individuals.

The private sector should receive encouragement to overcome the barriers facing the launch of innovative products. These barriers include the behavioral representation bias that affects unconventional financial instruments seeking to penetrate the markets and the agency costs that entail a relatively high level of information asymmetry and conflict of interest: subprime loans are a clear example [34].

Moreover, alternative financial products for which little historical information is available are regarded with suspicion by households, which perceive the risk to be too high. As a result, these products are expensive to commercialize and innovation is discouraged. In the main, only customers with sensation-seeking behavior tend to accept these innovative products [35].

This leads to a free-rider problem: that is, innovative financial institutions have greater difficulty in introducing new products due to the costs of educating the public and of generating historical data that can attract less prone-to-change households, and this highlights the need to introduce innovation and regulation, together with flexible systems, in order to adapt to continuous economic changes [36].

\section{Conclusions}

Properties represent a very large proportion of the total wealth in developed countries. Despite the potentially negative effects of financial markets, especially in the short term, the development of real estate finance on the basis of democratization and innovation is a source of economic growth.

If, in the last decade, the value of homes had been guaranteed, especially against the risk of price falls, the impact of the financial crises would have been vastly reduced. Against this background, a new framework of financial instruments that hedge property values is an unavoidable necessity for the well-being of society. Its creation may not be easy, but the recent crisis should encourage improvement and innovation.

Products, such as home equity value insurances, synthetic real estate, price level-adjusted mortgages, financial leasing for homeowners, and other hedging instruments, should be introduced in the markets in order to use finance for the benefit of society and, especially, of the most vulnerable individuals.

Given that homes are a primary need, governments should encourage innovation through policy incentives that reduce barriers to market entry and turn innovation into investment and economic value. In this regard, just as many financial entities require clients to take out life and home insurance when a new mortgage is signed, governments, international economic development organizations, labor unions, or professional organizations should help households to take optimal decisions to hedge or insure the values of the properties they own.

Summarizing, academics, governments, the financial industry, and households should all push for an improvement in the instruments available for owner-occupied property risk management to hedge asset values.

\section{References}

1. Case, K.E.; Quigley, J.M.; Shiller, R.J. Wealth Effects Revisited 1978-2009. Cowles Foundation. Yale University 2011, Discussion Paper 1784.

2. Case, K.E.; Quigley, J.M. How housing booms unwind: Income effects, wealth effects, and feedbacks through financial markets. Eur. J. Hous. Policy 2008, 8, 161-180. [CrossRef] 
3. Patel, K. Lessons from the FOX residential property futures and mortgage interest rate futures market. Hous. Policy Debate 1994, 5, 343-360. [CrossRef]

4. McCulloch, J.H. Risk characteristics and underwriting standards for price level adjusted mortgages versus other mortgage instruments. Hous. Financ. Rev. 1986, 5, 65-97.

5. Caplin, A.; Chan, S.; Freeman, C.; Tracy, J. Housing Partnerships: A New Approach to a Market at a Crossroads; MIT Press: Boston, MA, USA, 1997. Available online: http://goo.gl/jYN7tK (accessed on 10 September 2015).

6. Seiler, M.; Webb, J.; Myer, N. Diversification issues in real estate investment. J. Real Estate Lit. 1999, 7, $163-179$. [CrossRef]

7. Weiss, A.N.; Shiller, R.J. Home equity insurance. J. Real Estate Financ. Econ. 1999, 19, $21-47$.

8. Bakke, E. Income-Linked Loan Contracts in a Norwegian Perspective. Case: Norwegian State Education Loan Fund. Norges Handelshoyskole. 2006. Available online: http://goo.gl/bQjUQ1 (accessed on 20 September 2015).

9. Shiller, R.J. The New Financial Order: Risk in the 21st Century; Princeton University Press: Princeton, NJ, USA, 2009.

10. Pierson, M.W. REO to Rental: The Creation of a New Asset Class and the Transformation of the American Single Family Landscape. Ph.D. Thesis, Massachusetts Institute of Technology, Cambridge, MA, USA, 2014. Available online: http://goo.gl/dpNBvl (accessed on 2 October 2015).

11. Gaytan, A.; Ranciere, R. Wealth, Financial Intermediation and Growth. 2004. Working Papers Universitat Pompeu Fabra. Available online: https://goo.gl/gc388b (accessed on 2 October 2015).

12. Patrick, H.T. Financial development and economic growth in underdeveloped countries. Econ. Dev. Cult. Chang. 1966, 14, 174-189. [CrossRef]

13. Roig, J.; Soriano, J.M. Liquidez y cotización respecto al valor neto de los activos de los REIT españoles (las SOCIMI). Rev. Eur. Dir. Econ. Empres. 2015, 24, 92-107.

14. Green, R.K.; Wachter, S.M. The American mortgage in historical and international context. J. Econ. Perspect. 2005, 19, 93-114. [CrossRef]

15. Calavia, M. La Banca Vuelve a Dar Hipotecas por Hasta el 100\% del Valor de Tasación. CincoDías, 14 April 2015. Available online: http:/ /goo.gl/D88xQx (accessed on 4 October 2015).

16. Shiller, R.J. Why is Housing Finance Still Stuck in Such a Primitive Stage? Am. Econ. Rev. 2014, 104, 73-76. [CrossRef]

17. Roig, J. Análisis e Inversión en el Mercado Inmobiliario Desde Una Perspectiva Conductual. Ph.D. Thesis, Universitat Politècnica de Catalunya, Barcelona, Spain, 2015. Available online: http://goo.gl/ostk8X (accessed on 2 September 2015).

18. Glick, R.; Lansing, K.J. Global Household Leverage, House Prices, and Consumption. FRBSF Economic Letter, 11 January 2010. Available online: http:/ / goo.gl/v6JLAc (accessed on 4 October 2015).

19. Geanakoplos, J. Leverage, default, and forgiveness: Lessons from the American and European crises. J. Macroecon. 2014, 39, 313-333. [CrossRef]

20. Bernanke, B. Home Equity Insurance. Equity. Lock Financial, 2008. Available online: https://goo.gl/T3VKlE (accessed on 10 October 2015).

21. Gras, R.; Roig, J.; Soriano, J.M. Análisis y pronóstico del precio de la vivienda en España: Modelo econométrico desde una perspectiva conductual. Rev. Estud. Empres. 2015, 1, 145-166.

22. Sinai, T.M.; Souleles, N.S. Can Owning a Home Hedge the Risk of Moving? Working paper 15462; National Bureau of Economic Research: Cambridge, MA, USA, October 2009. Available online: http://goo.gl/o2lhcd (accessed on 10 October 2015).

23. O’Brien, J. A Revolutionary Help for Homeowners. The Christian Science Monitor, 26 November 2008. Available online: http:/ /goo.gl/nZsCta (accessed on 20 October 2015).

24. Shiller, R.J. Derivatives Markets for Home Prices; Working paper w13962; National Bureau of Economic Research: Cambridge, MA, USA, April 2008. Available online: http://goo.gl/nh1n1R (accessed on 20 October 2015).

25. Fernandez, J.; Llovera, F.J.; Roig, J. Los REITs españoles como vehículo de inversión y financiación de la actividad inmobiliaria: Las SOCIMI. Intang. Cap. 2012, 8, 308-363.

26. Fabozzi, F.J.; Shiller, R.J.; Tunaru, R.S. Property derivatives for managing European real estate risk. Eur. Financ. Manag. 2010, 16, 8-26. [CrossRef]

27. Baum, A. Real Estate Investment, 3rd ed.; Routledge, Taylor \& Francis Group: Oxford, UK, 2015.

28. Shiller, R.J. An Interview with Robert Shiller. The Politic, 3 April 2010. Available online: http://goo.gl/xfjaG7 (accessed on 2 September 2015). 
29. Sánchez, A.C.; Andrews, D. To Move or Not to Move: What Drives Residential Mobility Rates in 630 the OECD? Working paper 846; Organization for Economic Co-operation and Development: Paris, France, February 2011. Available online: http:/ /goo.gl/qXVkkt (accessed on 7 September 2015).

30. Cecohdas. Housing Market, Financial and Social Stability in Europe. 2014. Available online: http://goo.gl/ rTTB3D (accessed on 20 August 2015).

31. Kroszner, R.S.; Shiller, R.J. Reforming US Financial Markets; MIT Press: Boston, MA, USA, 2011.

32. Hellebrandt, T. The Economics and Estimation of Negative Equity. Quarterly Bulletin, Q2, 2009. Available online: http://goo.gl/ZtjSEP (accessed on 20 October 2015).

33. Duffy, D.; O'Hanlon, N. Negative equity in Ireland: Estimates using loan-level data. J. Eur. Real Estate Res. 2014, 7, 327-344.

34. An, X.; Deng, Y.; Gabriel, S.A. Asymmetric information, adverse selection, and the pricing of CMBS. J. Financ. Econ. 2011, 100, 304-325. [CrossRef]

35. Patoine, B. Desperately Seeking Sensation: Fear, Reward, and the Human Need for Novelty: Neuroscience Begins to Shine Light on the Neural Basis of Sensation-Seeking; Dana Foundation: New York, NY, USA, 2011.

36. La Porta, R.; Lopez-de-Silanes, F.; Shleifer, A.; Vishny, R.W. Legal determinants of external finance. J. Financ. 1997, 52, 1131-1150. [CrossRef]

(C) 2016 by the author; licensee MDPI, Basel, Switzerland. This article is an open access article distributed under the terms and conditions of the Creative Commons Attribution (CC-BY) license (http://creativecommons.org/licenses/by/4.0/). 